\title{
Gene expression and protein distribution of collagen, fibronectin and laminin in bovine follicles and corpora lutea
}

\author{
Y. Zhao and M. R. Luck* \\ Department of Physiology and Environmental Science, University of Nottingham, \\ Sutton Bonington Campus, Loughborough, Leics. LE12 5RD, UK
}

\begin{abstract}
The aim of this study was to locate sites of expression and deposition of collagen, fibronectin and laminin in the bovine ovary. RNA from the granulosa and basement membrane/theca fractions of maturing follicles and from corpora lutea of the early, middle and late luteal phase was probed with cDNAs for collagen types I and IV, fibronectin and laminin. Antisera against collagens I and IV were used in western analysis of protein from follicular fluid, granulosa, basement membrane/theca and corpus luteum. Collagen subunits $\alpha 1$ (I) and $\alpha 2$ (I) were expressed in the basement membrane/theca but not in the granulosa of the follicle. They were also expressed in all luteal extracts, especially those from the early phase. Collagen $\alpha 2$ (IV) was highly expressed in the basement membrane/theca and to a lesser extent in corpora lutea. Collagen $\alpha 3$ (IV) was expressed in the granulosa, basement membrane/theca and early corpus luteum. Fibronectin 1 and laminin B2 were expressed in all tissues. Laminin BI was expressed in all tissues except the granulosa. Collagen IV was immunodetected in all follicle extracts, with the strongest signal in the basement membrane/theca. Collagen I occurred in all luteal extracts and in the basement membrane/ theca but not in follicular fluid or the granulosa. These results demonstrate tissue-specific expression of ovarian structural proteins and suggest that changes occur during the progression from follicle to corpus luteum. The production of collagen IV in the follicle wall and of collagen $I$ in the corpus luteum is consistent with previous biochemical studies. Evidence for collagen IV in the follicular antrum suggests that the follicle wall originates from granulosa as well as theca cells. The expression of laminin and fibronectin in luteal as well as follicular tissues suggests a complex postovulatory extracellular matrix and provides a possible mechanism for the regulation of the endocrine cell phenotype by extracellular proteins.
\end{abstract}

\section{Introduction}

Tissue remodelling and cellular differentiation are a characteristic feature of the ovarian cycle. In particular, the transition from mature follicle to corpus luteum involves marked changes in tissue structure and alterations of the endocrine cell phenotype. In a range of tissues, extracellular matrix proteins regulate the cell phenotype during development, remodelling and repair (Hedin et al., 1988; Engel, 1991; Jones et al., 1993). There is increasing evidence for similar effects in reproductive tissues (Luck, 1994).

Collagens are the most abundant extracellular matrix proteins and consist of at least 16 classified types (Hulmes, 1992; Ayad et al., 1994). Their closely related polypeptide chains are encoded by at least 30 genes that exhibit tissue-specific expression. Collagen type I (fibrillar) predominates in connective tissues, while type IV (network) is exclusively present in basement membranes (van der Rest and Garrone, 1991;

*Correspondence.

Received 11 November 1994.
Hulmes, 1992). Fibronectin and laminin are large glycoproteins with collagen-, cell-, heparin- and other specific binding domains. Fibronectin $\left(M_{\mathrm{r}} 450000\right)$ is a heterodimer produced by a range of cell types and occurs in most body fluids and connective tissues. Laminin $\left(M_{\mathrm{r}} 900000\right)$ comprises disulphidelinked A, B1 and B2 subunits, and is found exclusively in association with basement membranes (Pikkarainen et al., 1988; Ayad et al., 1994).

The role of these proteins in the ovarian cycle is unclear, largely because their identity and locations within the ovary are poorly described (Luck, 1994). Follicular cells encounter a range of microenvironments, including the thecal matrix, the basement membrane, proteins and other macromolecules associated with the granulosa cells, the follicular fluid and the zona pellucida. Fibronectin and proteoglycans have been investigated in the antral compartment but the presence of other structural molecules, particularly collagen, is uncertain. The basement membrane, which compartmentalizes the follicle, is thought to comprise collagen type IV, laminin, entactin, fibronectin and heparan sulphate proteoglycan (Bagavandoss et al., 1983; Bertolussi et al., 1989; Luck, 1994) but its site of 
Table 1. cDNA probes used in northern blot analysis

\begin{tabular}{|c|c|c|c|c|c|}
\hline Clones & Origin & $\begin{array}{l}\text { Cloning vector and } \\
\text { selective antibiotic }\end{array}$ & Insert size & Restriction site & Reference \\
\hline $\begin{array}{l}\text { Collagen } \alpha 1(\mathrm{I}) \\
\mathrm{p} \alpha_{1} \mathrm{R} 1\end{array}$ & Rat & Puc 18 (Amp) & $1300 \mathrm{bp}$ & Pst/BamH I & 1 \\
\hline $\begin{array}{l}\text { Collagen } \alpha 2(\mathrm{I}) \\
\mathrm{p} \alpha_{2} \mathrm{R} 2\end{array}$ & Rat & Puc 18 (Amp) & $900 \mathrm{bp}$ & Pst/Pst & 1 \\
\hline $\begin{array}{l}\text { Collagen } \alpha 3(\mathrm{IV}) \\
\text { KEMC15 }\end{array}$ & Cow & pBSII(KS) (Amp) & $1500 \mathrm{bp}$ & EcoRI & 2 \\
\hline $\begin{array}{l}\text { Collagen } \alpha 2(\mathrm{IV}) \\
\text { Ac2 }\end{array}$ & Human placenta & Puc (Amp) & $4000 \mathrm{bp}$ & EcoRI & 3 \\
\hline $\begin{array}{l}\text { Fibronectin } 1 \\
\text { pFH111 }\end{array}$ & Human placenta & $\begin{array}{c}\text { pAT153/Pvull } / 8 \\
\text { pBR (Amp) }\end{array}$ & $150 \mathrm{bp}$ & BamH I/HindIII & 4,5 \\
\hline $\begin{array}{l}\text { Laminin B1 } \\
\text { HL- } 40\end{array}$ & Human placenta & pBR 322 (Amp) & $3800 \mathrm{bp}$ & EcoRI & 6,7 \\
\hline $\begin{array}{l}\text { Laminin B2 } \\
\text { HL-210 }\end{array}$ & Human placenta & pBR 322 (Amp) & $3600 \mathrm{bp}$ & EcoRI & 8,9 \\
\hline
\end{tabular}

1: Genovese et al. (1984); 2: Morrison et al. (1991a); 3: Hostikka and Tryggvason (1988); 4: Kornblihtt et al. (1985); 5: Gardella et al. (1989); 6: Pikkarainen et al. (1987); 7: Ikonen et al. (1989); 8: Pikkarainen et al. (1988); 9: Kallunki et al. (1989).

production is unknown, despite the need for rapid synthesis during follicle growth (Luck, 1994). Fibronectin is secreted by granulosa cells during early follicular development (Carnegie, 1990) and differentiation (Skinner and Dorrington, 1984; Skinner et al., 1985; Luck et al., 1991) but is present both in the basement membrane and as a soluble fraction of follicular fluid (Hung et al., 1989). Laminin has been immunolocalized to the basement membrane of growing and atretic follicles (Wordinger et al., 1983), and laminin and type III procollagen were reported in human preovulatory follicular fluid (Christiane et al., 1988).

Information on the extracellular matrix of the corpus luteum is particularly scarce. This tissue develops from that of the ovulated follicle, after enzyme-induced loss of basement membrane integrity and breakdown of the follicle wall. Angiogenesis, cell rearrangement and tissue growth occur, but the source and identity of luteal proteins are uncertain. Collagen type $I$ is a major component of the bovine corpus luteum (Luck and Zhao, 1993) but is not necessarily the only luteal collagen. The loss of the follicular basement membrane (type IV) and the subsequent growth of the corpus luteum (type I) suggest changes in the expression of individual structural protein genes within the ovary. This could alter substantially the range of proteins to which the endocrine cells are exposed and influence their differentiation (Luck et al., 1991; Luck, 1994).

In this study we have examined the expression of genes for collagen, fibronectin and laminin in tissue fractions of the mature follicle and developing corpus luteum. We have also used western immunoblotting to locate tissues in which collagen types I and IV are deposited.

\section{Materials and Methods}

\section{Reagents and chemicals}

A Random Primer Labelling kit for cDNA probe labelling and Rapid Hybridization Solution were purchased from
Stratagene (Cambridge). Poly ATtract mRNA Isolation kit, NBT (nitro blue tetrazolium) and BCIP (5-bromo-4-chloro-3indolyl-phosphate) substrates were from Promega (Madison, WI). Restriction enzymes were EcoRI (Appligene, Co. Durham), Hind III (GIBCO-BRL, Paisley), Pst and BamHI (Sigma, Poole). QIAGEN plasmid kit was from QIAGEN (Chatsworth, CA). Details of cDNA probes are given in Table 1 . Collagen $\alpha 1(\mathrm{I})$ and $\alpha 2(\mathrm{I})$ probes (Genovese et al., 1984) were provided by D. Rowe (University of Connecticut Health Centre). Collagen a3(IV) (Morrison et al., 1991a) was from M. Mariyama and S. T. Reeders (Yale University, School of Medicine). All other probes were from the American Type Culture Collection, Rockville, MD. Polyclonal rabbit anti-human collagen type I was from HyClone, Logan, UT. Monoclonal goat anti-human/ bovine collagen type IV was from Sera-Lab (Crawley Down, Sussex). Alkaline phosphatase-conjugated whole molecule antirabbit IgG and monoclonal anti-goat IgG were from Sigma. $\alpha-32 \mathrm{p}-\mathrm{dCTP}$ Redivue $\left(3000 \mathrm{Ci} \mathrm{mmol}^{-1}\right)$ was from Amersham (Bucks). Other reagents were from Sigma or Bio-Rad arıd of molecular biology or analytical grade.

\section{Granulosa cell isolation and tissue preparation}

Fresh bovine ovaries were obtained from a local abattoir and transported to the laboratory on ice. Ovaries of unrecorded cycle stage but with single, mature, healthy preovulatory follicles $(1-3 \mathrm{ml})$ were selected for granulosa cell preparation as described by Luck (1990) with slight modification. After withdrawal of follicular fluid (retained at $-20^{\circ} \mathrm{C}$ for western blot) by syringe and needle, the follicle was injected with PBS and the cells of the inner follicular surface gently scraped using an inoculation loop. The cell suspension was aspirated and transferred to a sterile tube; cells from several follicles were pooled in this manner. Cell pellets were obtained by centrifugation $\left(250 \mathrm{~g}, 15 \mathrm{~min}, 4^{\circ} \mathrm{C}\right)$. Immediately after granulosa cell removal, the basement membrane/theca interna tissue was carefully pulled from the follicle wall using fine forceps. 
Samples were stored at $-70^{\circ} \mathrm{C}$ before extraction of RNA or protein.

Healthy ovaries bearing corpora lutea were selected and rinsed in physiological saline. Corpora lutea were carefully excised and the capsule membrane removed. They were classified according to their morphology (Ireland et al., 1980) into the following approximate periods of the luteal phase: stage I: days 1-4 (early stage); stages II and III: days 5-17 (middle stage); stage IV: days 18-20 (late stage). Tissue was stored at $-70^{\circ} \mathrm{C}$.

\section{Northern blot hybridization}

Total RNA was isolated from granulosa cells, basement membrane/theca, or corpora lutea by acid guanidinium thiocyanate-phenol-chloroform extraction (Chomczynski and Sacchi, 1987). The poly $(A)+$ RNA fraction was purified using the Poly ATtract mRNA Isolation System (Promega). After heat denaturation of total RNA $\left(65^{\circ} \mathrm{C}, 10 \mathrm{~min}\right)$, biotinylatedoligo(dT) was mixed with RNA to allow the annealing of oligo(dT) with the $3^{\prime}$-poly $(\mathrm{A})+$ region of mRNA. The hybrids were washed with $0.1 \times$ SSC $($ SSC $=0.15 \mathrm{~mol}$ sodium chloride $\mathrm{I}^{-1}, 0.015 \mathrm{~mol}$ sodium citrate $\mathrm{l}^{-1}, \mathrm{pH} 7.0$ ) and captured by means of streptavidin-coupled magnetic particles. The mRNA was eluted from the solid phase with water and precipitated by 1/10 volume of $3 \mathrm{~mol}$ sodium acetate $\mathrm{l}^{-1}(\mathrm{pH}$ 7.0). Twenty micrograms of total RNA or $5 \mu \mathrm{g}$ of poly $(\mathrm{A})+\mathrm{RNA}$ was subjected to electrophoresis through $1 \%(w / v)$ agarose gel in MOPS buffer (20 mmol 3- $\mathrm{N}$-morpholinol-propanesulfonic acid $1^{-1}, 5 \mathrm{mmol}$ sodium acetate $1^{-1}, 1 \mathrm{mmol}$ EDTA $\mathrm{l}^{-1}, \mathrm{pH}$ 6.4) with $5.5 \%(\mathrm{v} / \mathrm{v})$ formaldehyde and then transferred to Hybond-N membrane (Amersham). RNA integrity was confirmed by ethidium bromide staining for $28 \mathrm{~S}$ and $18 \mathrm{~S} r \mathrm{RNA}$ in total RNA and by the cDNA probe detection of intact mRNAs in both total and poly $(\mathrm{A})+$ RNA blots. Total RNA from human placenta (kindly supplied by F. Broughton-Pipkin and S. Green, Department of Obstetrics and Gynaecology, Queen's Medical Centre, Nottingham) served as a positive control for laminin $\mathrm{CDNA}$ probes.

cDNA inserts were isolated by restriction cleavage from plasmids in bacterial cultures grown in the presence of selective antibiotics (Table 1). Plasmids were purified using QIAGEN tips according to Birnboim and Doly (1979) with modification. Isolated cDNA inserts were used to synthesize $a^{32} \mathrm{P}-\mathrm{dCTP}$ labelled probes using random primer labelling (Feinberg and Vogelstein, 1983). After prehybridization ( $15 \mathrm{~min}, 62^{\circ} \mathrm{C}$, QuickHyb), hybridization $\left(2 \mathrm{~h}, 62^{\circ} \mathrm{C}\right)$ was carried out in the presence of the denatured ${ }^{32} \mathrm{P}$-labelled $\mathrm{cDNA}$ probe. The filter was washed twice with $2 \times \mathrm{SSC} / 0.1 \%$ SDS (w/v; $15 \mathrm{~min}$, room temperature) and then once with $0.1 \times \mathrm{SSC} / 0.1 \% \mathrm{SDS}\left(62^{\circ} \mathrm{C}\right.$, $30 \mathrm{~min}$ to $2 \mathrm{~h}$ depending on the probe) to achieve a high stringency wash. After air drying, the membrane was wrapped in plastic film and exposed to Kodak X-Omat AR film with an intensifying screen at $-70^{\circ} \mathrm{C}$. The exposure time varied between overnight and eight days according to signal intensity.

\section{SDS-PAGE and western blot}

Protein was extracted for western blot according to Miller and Rhodes (1982) with modifications. The tissue was homog- enized in buffer $\left(4.5 \mathrm{~mol}\right.$ sodium chloride $1^{-1}, 0.05 \mathrm{~mol}$ Tris $\mathrm{l}^{-1}, 20.0 \mathrm{mmol}$ EDTA $\mathrm{l}^{-1}, 1.0 \mathrm{mmol}$ diisopropyl fluorophosphate $1^{-1}, 2.0 \mathrm{mmol} N$-ethylmaleimide $1^{-1}, 1 \mu \mathrm{g}$ pepstatin $\left.\mathrm{ml}^{-1}, \mathrm{pH} 7.5\right)$ and centrifuged $(12000 \mathrm{~g}, 15 \mathrm{~min})$. The pellet was washed by resuspension and centrifugation, and then washed with water, containing EDTA and the proteinase inhibitors, to remove salt. It was finally resuspended in $0.5 \mathrm{~mol}$ acetic acid $\mathrm{l}^{-1}\left(\mathrm{pH} 2.5\right.$, plus $20 \mathrm{mmol}$ EDTA $\mathrm{l}^{-1}$ and protease inhibitors) with continuous vigorous stirring $(5 \mathrm{~h})$. The dispersed tissue was filtered through nylon mesh and centrifuged $(5000 \mathrm{~g}, \mathrm{I} \mathrm{h})$. The crude collagen pellet was dissolved in $0.012 \mathrm{~mol} \mathrm{HCl} \mathrm{l}^{-1}$ stored at $4^{\circ} \mathrm{C}$.

Protein preparations or unextracted follicular fluid were subjected to 6\% SDS-PAGE (Laemmli, 1970), under reducing and nonreducing conditions, and transferred electrophoretically to nitrocellulose filters (Bio-Rad) according to Towbin et al. (1979). The molecular weight marker lane was removed and stained by colloidal gold. The remaining lanes were immunoblotted with anti-collagen antisera as follows. After blocking nonspecific sites $(5 \%(\mathrm{w} / \mathrm{v})$ skim milk, $0.1 \%(\mathrm{v} / \mathrm{v})$ Tween 20 in PBS), the blot was incubated ( $1 \mathrm{~h}$ ) with either 1:5000 anticollagen type I or 1:5000 anti-collagen type IV. The blot was washed (PBS with $0.5 \%(\mathrm{v} / \mathrm{v})$ Tween 20$)$ to remove unbound antibodies and incubated (1 h) in 1:8000 alkaline phosphataseconjugated anti-rabbit or anti-goat IgG in the same buffer. The colour reaction was performed using NBT and BCIP as substrate (Blake et al., 1984).

Each northern and western analysis was performed two or three times, on separate extracts, with similar results in each case. Representative data is presented and only consistent signals are discussed. Owing to the uncertain efficiencies of sample extraction procedures, particularly of collagens, no attempt was made to quantify signals.

\section{Results}

\section{Expression of collagen type I}

Collagen $\alpha 1(1)$ subunit was not expressed in the granulosa but was present in the basement membrane/theca fraction of the follicle as bands at 5.8 and $4.8 \mathrm{~kb}$ (Fig. Ia). The gene was transcribed in all luteal extracts but to the greatest extent (as a proportion of the loaded mRNA) during the early luteal phase. Expression of the collagen $\alpha 2$ (I) subunit showed a similar pattern (Fig. Ib).

\section{Expression of collagen type IV}

Expression of the $\alpha 2$ (IV) subunit was strong in the basement membrane/theca but was not detected in the granulosa (Fig. 2a). Expression occurred in early and late stage corpora lutea but to a lesser extent than in the basement membrane/theca. The $\alpha 3$ (IV) subunit was expressed as an $8.0 \mathrm{~kb}$ transcript, as reported by Morrison et al. (1991b) in both follicle fractions, but with greater intensity in the basement/membrane theca (Fig. 2b). It was also detected in the early corpus luteum, but showed a different transcription pattern with an extra band at $4.0 \mathrm{~kb}$. Neither band was detected in the late phase corpus luteum. 
(a)

$\mathrm{kb}$

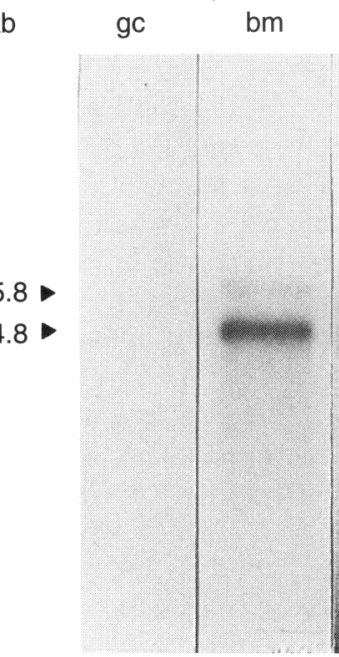

(b)

$\mathrm{kb}$

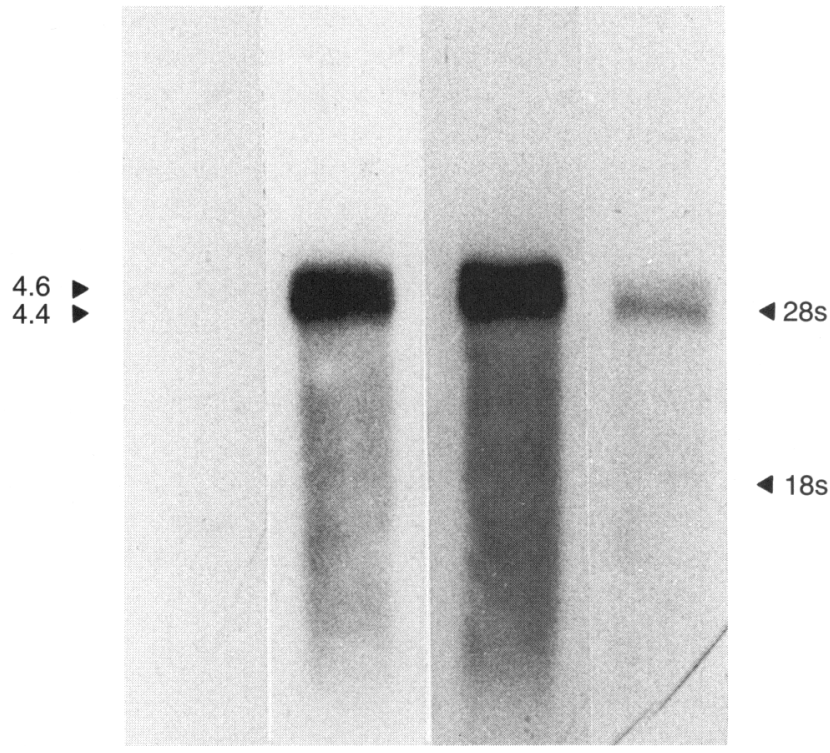

Fig. 1. Northern blot analysis of poly(A) + RNA from bovine ovarian tissues, $5 \mu \mathrm{g}$ per lane, hybridized with $\mathrm{cDNAs}$ for (a) rat collagen $\alpha \mathrm{I}(\mathrm{I})$ (clone $p \alpha_{1} R 1$ ), and (b) rat collagen $\alpha 2(\mathrm{I})$ (clone $p \alpha_{2} R 2$ ). Tissue fractions: gc: granulosa cells; bm: basement membrane/theca; $\mathrm{CL}$ : corpus luteum from early (e), middle $(\mathrm{m})$ and late (l) luteal phase. Autoradiographic exposure was for $24 \mathrm{~h}$.

\section{Expression of fibronectin}

The fibronectin 1 chain (FN1) was expressed in all ovarian fractions (Fig. 3). The main mRNA transcript was at $7.8 \mathrm{~kb}$ but additional, smaller signals appeared in some fractions. In the early corpus luteum, where expression of the $7.8 \mathrm{~kb}$ transcript was relatively low, dense signals appeared in the region of $4.8-5.8 \mathrm{~kb}$.

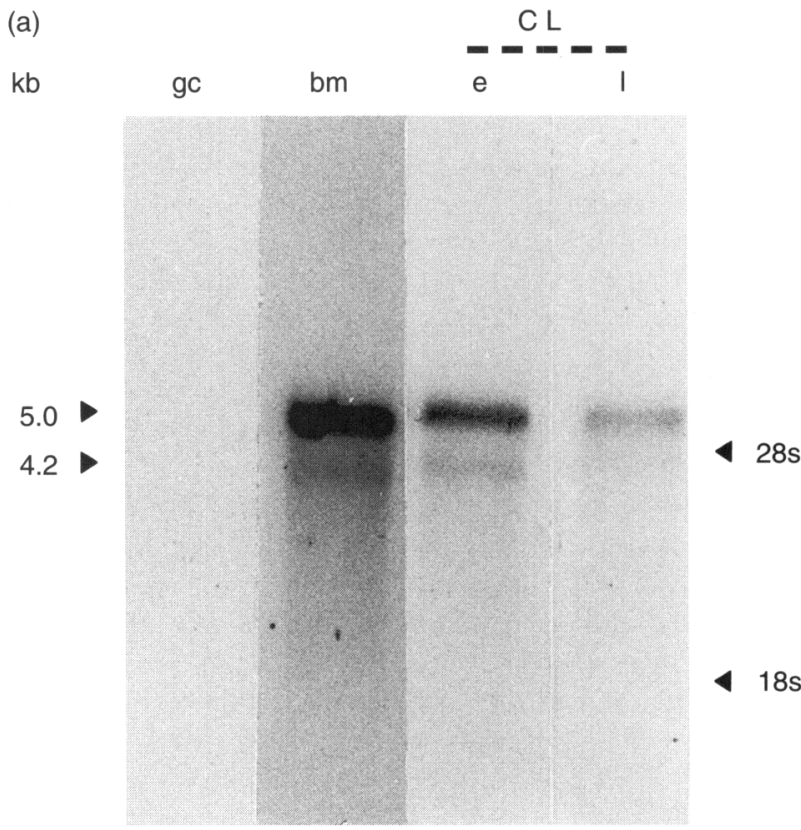

(b)

C L

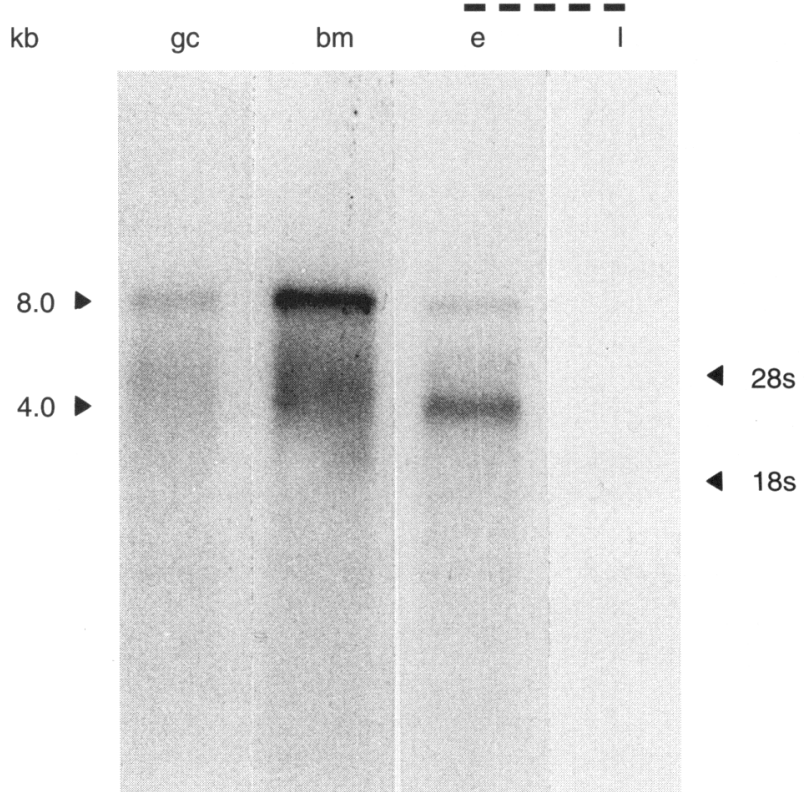

Fig. 2. Northern blot analysis of poly(A) + RNA from bovine ovarian tissues, $5 \mu \mathrm{g}$ per lane, hybridized with cDNAs for (a) human collagen $\alpha 2$ (IV) (clone Ac2), and (b) bovine $\alpha 3$ (IV) (clone KEMC15). Tissue fractions: gc: granulosa cells; bm: basement membrane/theca; $\mathrm{CL}$ : corpus luteum from early (e) and late (l) luteal phase. Autoradiographic exposure was for $48 \mathrm{~h}$.

\section{Expression of laminin}

Laminin B1 was expressed in the basement membrane/theca and corpora lutea but it was not detectable in the granulosa cells (Fig. 4a). The B2 subunit mRNA was expressed in the granulosa cells and basement membrane/theca as well as the 


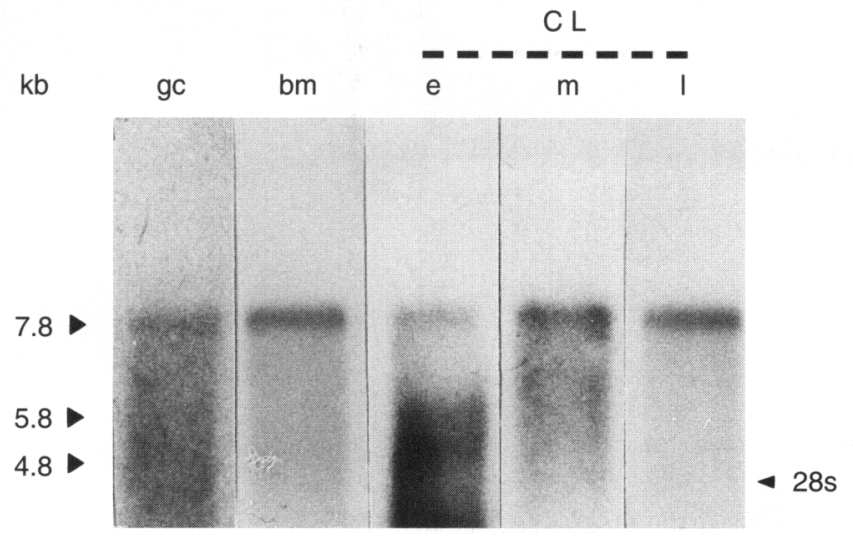

Fig. 3. Northern blot analysis of poly $(A)+$ RNA from bovine ovarian tissues, $5 \mu \mathrm{g}$ per lane, hybridized with cDNA for fibronectin 1 (clone pFH111). Tissue fractions: gc: granulosa cells; bm: basement membrane/theca; $\mathrm{CL}$ : corpus luteum from early $(\mathrm{e})$, middle $(\mathrm{m})$ and late (l) luteal phase. Autoradiographic exposure was $24 \mathrm{~h}$.

corpora lutea (Fig. 4b). The B2 mRNA gave a more intense signal than did the B1; it appeared as two transcripts at 7.5 and $5.5 \mathrm{~kb}$ in a human placental extract used as positive control (Pikkarainen et al., 1987, 1988), but as a single $7.5 \mathrm{~kb}$ transcript in the bovine ovarian extract.

\section{Immunoblotting of collagen}

The granulosa extract and the follicular fluid failed to give a positive signal when anti-collagen type I was used for immunodetection (Fig. 5). Luteal extracts showed positive staining. The basement membrane/theca extract also gave a strong reaction with distinct bands corresponding to the $\alpha 2$ and $\beta$ subunits of the standard collagen. Additional bands were observed in the high molecular weight regions of the positively reacting tissue extracts. A positive reaction to anti-collagen type IV was seen in all follicular extracts at between $100 \mathrm{kDa}$ and $110 \mathrm{kDa}$ under reduced conditions (Fig. 6a). A signal from the late phase corpus luteum extract was also detected. Under nonreduced conditions (Fig. 6b), the pattern of reaction was similar but the stained bands were larger (110-160 kDa). A particularly strong signal was seen in follicular fluid.

\section{Discussion}

This study demonstrates a tissue-specific distribution of extracellular matrix proteins within the ovary. Collagen type $I$ is expressed and deposited within the corpus luteum, whereas type IV is predominantly associated with the follicular basement membrane. Fibronectin and laminin are both expressed before and after ovulation. In addition to these broad conclusions, our data indicate specific tissue sites of synthesis of individual collagens. They also demonstrate some continuity of gene expression during the remodelling of follicular tissues to form the corpus luteum.

Collagen type I can be resolved by SDS-PAGE into several subunits including $\alpha 1$ and $\alpha 2$, each of which is just over 1000 residues in length, and a number of $\beta$ subunits (Linsenmayer,
1991). In the present western analysis, we detected the $\alpha 2$ chain plus two, more slowly migrating, $\beta$ chains at around $200-250 \mathrm{kDa}$. For the northern analysis, we used probes representing (i) approximately 500 amino acid residues within the triple helical region of the $\alpha I$ subunit (paIRI) and (ii) sequences specific to the $3^{\prime}$ noncoding region and carboxyterminal propeptide region of $\alpha 2$ subunit ( $p a 2 R 2$ ). The transcripts at 5.8 and $4.8 \mathrm{~kb}$ for $\alpha I(\mathrm{I})$ and at 4.6 and $4.4 \mathrm{~kb}$ for $\alpha 2(\mathrm{I})$ provide a pattern similar to that observed in humans and rats (Genovese et al., 1984; Myers et al., 1986).

Type I collagen was expressed and deposited in the corpus luteum, as reported from biochemical analysis by Luck and Zhao (1993). However, clear signals for this collagen also appeared in the basement membrane/theca fraction of the follicle. This fraction includes, in addition to the basement membrane, cellular and non-cellular material of the theca interna. Since collagen I does not occur in basement membranes, the detected collagen is part of the supporting matrix of the theca and originates from thecal cells. The exact cell type(s) responsible remain to be determined.

Theca interna-derived cells contribute significantly to the development of bovine luteal tissue from the ovulated follicle (Hansel et al., 1991). The detection of collagen I in the basement membrane/theca fraction makes it possible to account for the large amounts of this collagen in the developing corpus luteum by an increase in gene expression in theca-derived cells, rather than by a postovulatory initiation as previously suggested (Luck and Zhao, 1993). No evidence for collagen type I production in the granulosa/follicular fluid compartment was found in this study. The possibility that granulosa-derived cells contribute to the luteal matrix, as a result of postovulatory differentiation, remains to be examined. Both collagen I subunits ( $\alpha$ and $\beta$ ) were strongly expressed in the late luteal phase. It was concluded previously that noncollagenic material is preferentially lost during luteolysis (Luck and Zhao, 1993); the results reported here indicate that collagen synthesis remains active during this period of the ovarian cycle.

Collagen type IV was immunodetected, as expected, in the basement membrane/theca fraction. Two of its subunits $(\alpha 2$ and a3) were expressed, together with those of the basement membrane-associated glycoprotein, laminin. However, immunoreactive type IV was also present in the granulosa and follicular fluid extracts and there was evidence of $\alpha 3$ subunit expression in the granulosa cells. These data indicate that cells from both the thecal and granulosal sides of the basement membrane contribute to its production. Follicular growth requires an increase in the surface area of the follicle wall in proportion to the square of the follicle radius. Granulosa cells can secrete basement membrane components in culture (Lavranos et al., 1994) but the physiology of the process in vivo is unknown. It presumably requires intensive protein synthesis together with turnover of existing membrane material. The presence of material that reacts with type IV antiserum in the follicular fluid and granulosa fractions, neither of which contains distinct membranes, may be the result of basement membrane turnover during the growth process.

Collagen type IV comprises three $\alpha$ subunits, selected from six distinct gene products designated $\alpha 1$ (IV) to $\alpha 6$ (IV) (Ayad et al., 1994). The most abundant form has the composition $\left[\alpha 1(\text { IV) }]_{2} \alpha 2\right.$ (IV). The $\alpha 3$ subunit occurs less frequently but has 

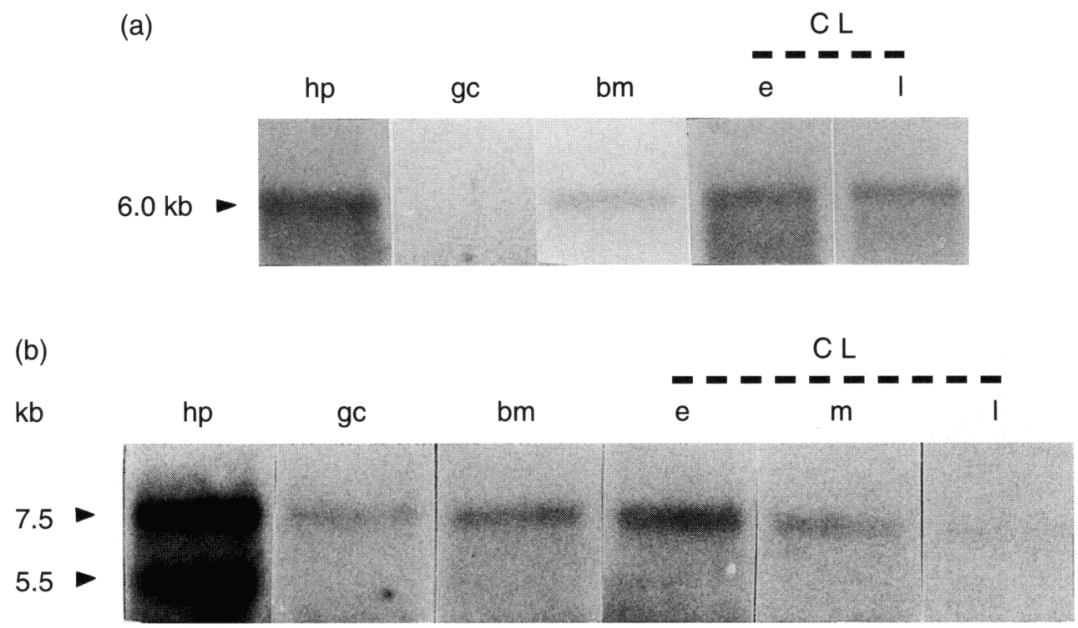

Fig. 4. Northern blot analysis of total RNA from bovine ovarian tissues, $20 \mu \mathrm{g}$ per lane, hybridized with cDNAs for (a) laminin BI (clone HL-40), autoradiographic exposure was for 8 days, and (b) laminin B2 (clone HL-210), exposure for 3 days. Tissue fractions: hp: human placenta (positive control); gc: bovine granulosa cells; bm: basement membrane/ theca; CL: corpus luteum from early (e), middle (m) and late (l) luteal phase.

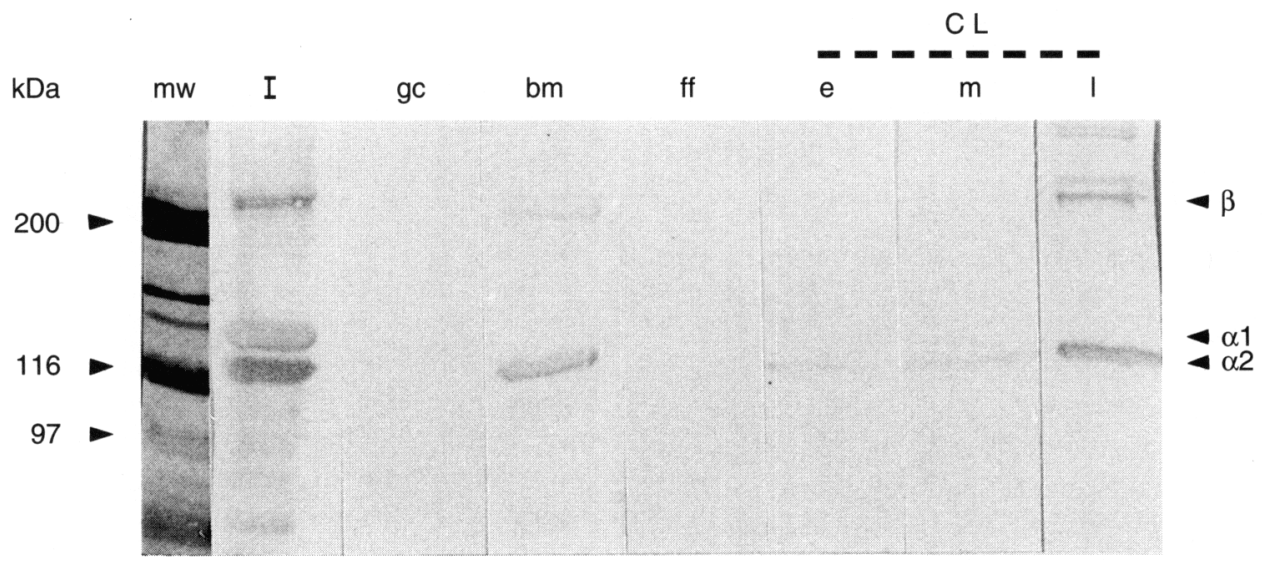

Fig. 5. Western immunoblot analysis of protein from bovine ovarian tissues under nonreducing conditions, probed with a rabbit antiserum raised against human collagen type I; alkaline phosphataselinked second antibody. mw: molecular weight marker; I: human placental collagen type I (Sigma). Tissue fractions: gc: granulosa cells; bm: basement membrane/theca; ff: follicular fluid; CL: corpus luteum from early (e), middle $(\mathrm{m})$ and late (l) luteal phase. Positions of collagen subunits $\alpha 1, \alpha 2$ and $\beta$ are indicated.

been isolated from bovine basement membranes and sequenced (Morrison et al., 1991a; Ayad et al., 1994). The transcript size for $\alpha 2$ (IV) is not reported but in our study appeared as two bands, at 5.0 and $4.2 \mathrm{~kb}$. The major mRNA size for $\alpha 3$ (IV) was $8.0 \mathrm{~kb}$, as reported by Morrison et al. (1991b), but, in the present study, an additional transcript of $4.0 \mathrm{~kb}$ was observed in the early corpus luteum. The significance of this is unclear but it may reflect tissue-specific processing of the gene products.

The expression of type IV collagen in the corpus luteum was not anticipated on the basis of earlier biochemical analysis (Luck and Zhao, 1993). Extraction procedures for network collagen are relatively inefficient and it is possible that the quantity obtained in that study was below the sensitivity of the nonspecific protein staining which was used. In the present study, expression of the $\alpha 2$ and $\alpha 3$ subunits was detected, particularly in early luteal tissue, and immunological evidence for type IV in the late luteal extract was found. Taken together with the expression of laminin at all luteal stages and the presence of laminin immunoreactivity in murine corpora lutea (Wordinger et al., 1983), these data are strong evidence for the presence of basement membrane-like structures in the corpus luteum. The identity of these structures remains to be determined, but it is likely that they are associated with the extensive vascularization of the tissue (Zheng et al., 1993; Luck et al., 1995).

The laminin BI subunit was transcribed at a relatively lower intensity than was the $\mathrm{B} 2$ in the basement membrane/theca and corpus luteum, and was absent from the granulosa. Laminin contains three subunits, A, B1 and B2, which occur in equimolar ratios (Timpl et al., 1979) but may be transcribed at different rates according to tissue type and age (Boot-Handford et al., 

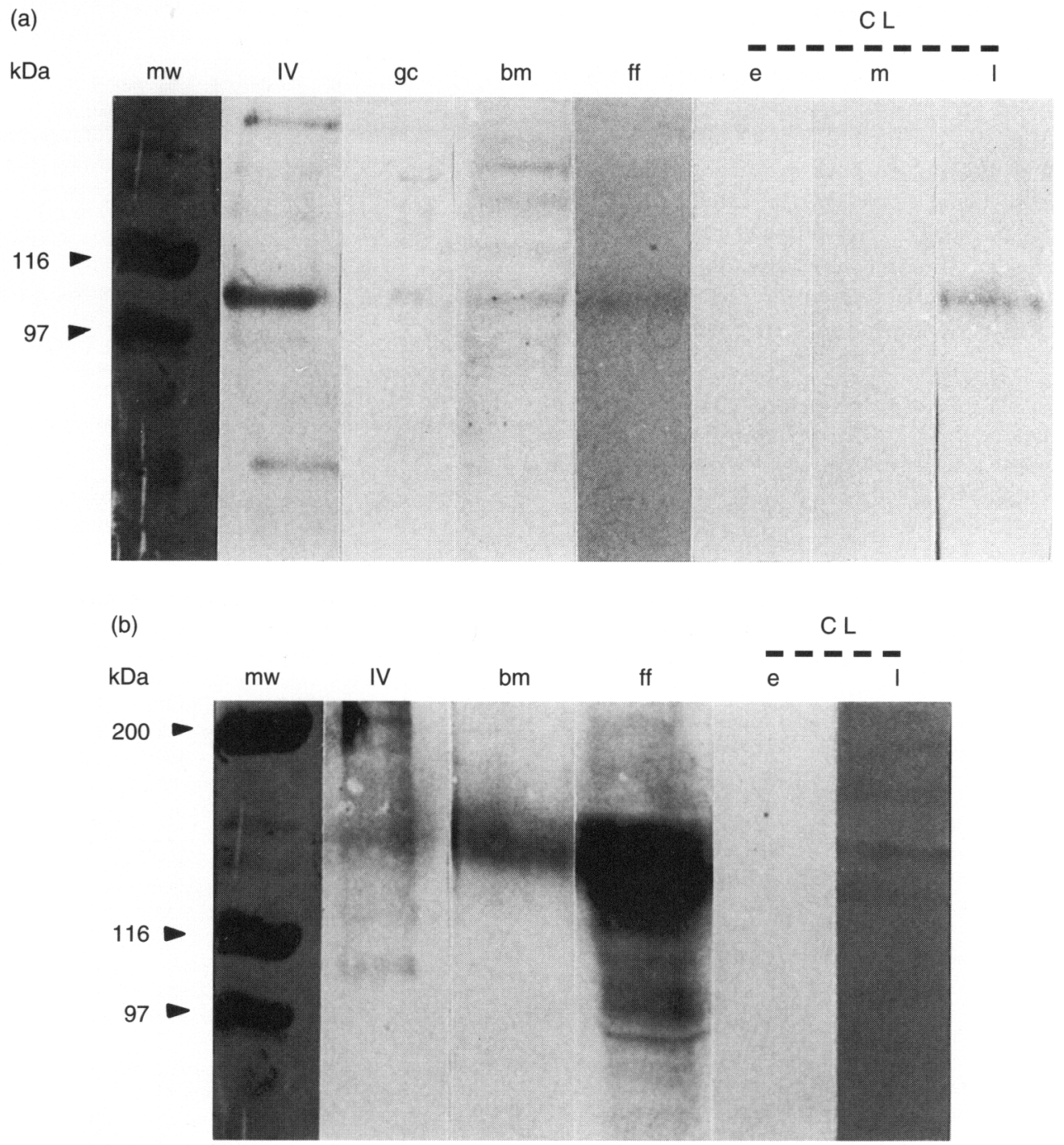

Fig. 6. Western immunoblot analysis of protein from bovine ovarian tissues under (a) reducing and (b) nonreducing conditions, probed with a goat antibody raised against human/bovine collagen type IV; alkaline phosphatase-linked second antibody. mw: molecular weight marker; IV: human placental collagen type IV (Sigma); gc: granulosa cells; bm: basement membrane/theca; ff: follicular fluid; CL: corpus luteum from early (e), middle $(\mathrm{m})$ and late (l) luteal phase.

1987). Other molecular assemblies, such as homodimeric and heterodimeric B chain pairs, also occur (Pikkarainen et al., 1988). Such arrangements may explain observations of single (bovine) and dual (human) transcripts but require further investigation.

Fibronectin was expressed in all the tissues examined, which is consistent with its role as a ubiquitous linking and signalling molecule between cells and extracellular surfaces. The presence of fibronectin in the follicle and its synthesis by differentiating granulosa cells is well established (Bagavandoss et al., 1983; Skinner and Dorrington, 1984; Skinner et al., 1985; Carnegie, 1990; Luck et al., 1991), but this is the first direct evidence of its synthesis in the basement membrane/theca and corpus luteum. We conclude that cells from both sides of the basement membrane contribute to fibronectin production both before and after ovulation, perhaps with changes in rates of expression and synthesis.
An apparent change in the fibronectin RNA band distribution was observed between tissues at different cycle stages. A $7.8 \mathrm{~kb}$ transcript was present in all fractions, similar to that reported for human fibronectin (Kornblihtt et al., 1983; Bernard et al., 1985; Levy et al., 1994), but there were additional positive reactions in several lanes (Fig. 3). Additional hybridization bands (5.8 and $4.8 \mathrm{~kb}$ ) in poly(A) + RNA from human fibroblasts have been reported (Bernard et al., 1985). These positions were shown in the study reported here to incorporate part of the heavily reacting shorter length region in the early luteal lane. Fibronectin shares common amino acid sequences with collagen $\alpha 1(\mathrm{I})$ and $\alpha 2(\mathrm{I})$, including the highly conserved Arg-Gly-Asp (RGD) cell-binding sequence (Dedhar et al., 1987) and the additional signals may represent detection of these transcripts in RNAs encoding collagen by the fibronectin probe (Bernard et al., 1985). 
In summary, our study demonstrates the tissue-specific expression of extracellular matrix proteins in the bovine follicle and corpus luteum. Collagen type I is produced in the theca, as well as being a major protein of the corpus luteum. Type IV occurs in the follicle wall and in the antral compartment and may be synthesized by cells on both sides of the basement membrane. Type IV occurs in the corpus luteum, together with laminin, indicating that there are postovulatory basement membrane structures. Fibronectin is expressed in all the tissues studied, providing the potential for specific, receptor-mediated cell-protein interactions during the ovarian cycle.

The authors thank $D$. Rowe for providing the $\alpha I$ (I) and $\alpha 2$ (I) cDNA probes, M. Mariyama and S. T. Reeders for the $\alpha 3$ (IV) probe, F. Broughton-Pipkin and S. Green for placental material, R. Duffy for work on the fibronectin probe and L. Durrant for assistance with western blotting. Supported by the Wellcome Trust (grant no. $035413 / \mathrm{Z} / 92 / \mathrm{Z}$ ).

\section{References}

Ayad S, Boot-Handford RP, Humphries MJ, Kadler KE and Shuttleworth AC (1994) The Extracellular Matrix Facts Book pp 40-45. Academic Press, London Bagavandoss P, Midgley AR and Wicha M (1983) Developmental changes in the ovarian follicular basal lamina detected by immunofluorescence and electron microscopy Joumal of Histochemistry and Cytochemistry 31 633-640

Bernard MP, Kolbe M, Weil D and Chu ML (1985) Human cellular fibronectin: comparison of the carboxyl-terminal portion with rat identifies primary structural domains separated by hypervariable regions Biochemistry 24 2698-2704

Bertolussi M, Zanchetta R, Doliana R, Castellani I, Bressan GM and Lauria A (1989) Changes in the organization of the extracellular matrix in ovarian follicles during the preovulatory phase and atresia: an immunofluorescence study Basic and Applied Histochemistry 33 31-38

Birnboim HC and Doly J (1979) A rapid alkaline extraction procedure for screening recombinant plasmid DNA Nucleic Acids Research 7 1513-1522

Blake MS, Johnston KH, Russell Jones GJ and Gotschlich EC (1984) A rapid, sensitive method for the detection of alkaline phosphatase-conjugated anti-antibody on western blots Analytical Biochemistry 136 175-179.

Boot-Handford RP, Kurkinen M and Prockop DJ (1987) Steady-state levels of mRNA coding for the type IV collagen and laminin polypeptide chains of basement membranes exhibit marked tissue-specific stoichiometric variations in the rat Journal of Biological Chemistry 26212 475-12 478

Carnegie JA (1990) Secretion of fibronectin by rat granulosa cells occurs primarily during early follicular development journal of Reproduction and Fertility 89 579-589

Chomczynski P and Sacchi N (1987) Single-step method of RNA isolation by acid guanidinium thiocyanate-phenol-chloroform extraction Analytical Biochemistry 162 156-159

Christiane Y, Lambotte R, Demoulin A, Lapiere CM, Gillain D, Nusgens B, Leroy $\mathbf{F}$ and Foidart JM (1988) Laminin and type III procollagen peptide in human preovulatory follicular fluid Fertility and Sterility 50 48-51

Dedhar S, Ruoslahti E and Piersbacher MD (1987) A cell surface receptor complex for collagen type I recognizes the ARG-GLY-ASP sequence Journal of Cell Biology $104585-593$

Engel J (1991) Common structural motifs in proteins of the extracellular matrix Current Opinion in Cell Biology 3 779-785

Feinberg AP and Vogelstein B (1983) A technique for radiolabelling DNA restriction endonuclease fragments to high specific activity Analytical Biochemistry 132 6-13

Gardella R, Colombi M and Barlati S (1989) A new Taq1 RFLP of the human fibronectin (FN1) gene Nucleic Acids Research 1710520

Genovese C, Rowe D and Kream B (1984) Construction of DNA sequences complementary to rat $\alpha 1$ and $\alpha 2$ collagen mRNA and their use in studying the regulation of type I collagen synthesis by 1,25-dihydroxyvitamin D Biochemistry 23 6210-6216
Hansel W, Alila HW, Dowd JP and Milvae RA (1991) Differential origin and control mechanisms in small and large bovine luteal cells Journal of Reproduction and Fertility Supplement 43 767-789

Hedin U, Bottger BA, Forsberg E, Johansson S and Thyberg J (1988) Diverse effects of fibronectin and laminin on phenotypic properties of cultured arterial smooth muscle cells Journal of Cell Biology 107 307-319

Hostikka SL and Tryggvason K (1988) The complete primary structure of the $\alpha 2$ chain of human type IV collagen and comparison with the $\alpha \mathrm{I}(\mathrm{IV})$ chain journal of Biological Chemistry $26319488-19493$

Hulmes DIS (1992) The collagen superfamily - diverse structures and assemblies Essays in Biochemistry 27 49-67

Hung TT, Tsuiki A and Yemini M (1989) Fibronectin in reproduction Steroids 54 $575-582$

Ikonen J, Pikkarainen T, Savolainen ER and Tryggvason K (1989) A Hpa I polymorphism in the human laminin B1 chain gene on $7 \mathrm{q} 22$ Nucleic Acids Research 17473

Ireland JJ, Murphee RL and Coulson PB (1980) Accuracy of predicting stages of bovine oestrous cycle by gross appearance of corpus luteum Journal of Dairy Science 63 155-160

Jones PL, Schmidhauser C and Bissell MJ (1993) Regulation of gene expression and cell function by extracellular matrix Critical Reviews of Eukaryotic Gene Expression 3 137-154

Kallunki T, Pikkarainen T, Tryggvason K and Savolainen ER (1989) A Pst I polymorphism in the human laminin B2 chain gene on $1 \mathrm{q} 25 \rightarrow \mathrm{q} 31$ Nucleic Acids Research 174423

Kornblihtt AR, Vibe-Pedersen K and Baralle FE (1983) Isolation and characterization of $\mathrm{CDNA}$ clones for human and bovine fibronectins Proceedings of the National Academy of Sciences USA 80 3218-3222

Kornblihtt AR, Umezawa K, Vibe-Pedersen K and Baralle FE (1985) Primary structure of human fibronectin - differential splicing may generate at least 10 polypeptides from a single gene EMBO Journal 4 1755-1759

Laemmli UK (1970) Cleavage of structural proteins during the assembly of the head of bacteriophage T4 Nature $227680-685$

Lavranos TC, Rodgers HF, Bertoncello I and Rodgers RJ (1994) Anchorageindependent culture of bovine granulosa cells: the effects of basic fibroblast growth factor and dibutyryl cAMP on cell division and differentiation Experimental Cell Research $211245-251$

Levy P, Loreal O, Munier A, Yamada Y, Picard J, Cherqui G, Clement B and Capeau J (1994) Enterocytic differentiation of the human caro-2 cell line is correlated with down-regulation of fibronectin and laminin FEBS Letters 338 $272-276$

Linsenmayer TF (1991) Collagen. In Cell Biology of Extracellular Matrix pp 7-43 Ed. ED Hay. Plenum Press, New York

Luck MR (1990) Cholinergic stimulation through muscarinic receptors, of oxytocin and progesterone secretin from bovine granulosa cells undergoing spontaneous luteinization in serum-free culture Endocrinology 126 1256-1263

Luck MR (1994) The gonadal extracellular matrix Oxford Reviews of Reproductive Biology 16 33-85

Luck MR and Zhao $Y$ (1993) Identification and measurement of collagen in the bovine corpus luteum and its relationship with ascorbic acid and tissue development Journal of Reproduction and Fertility $99647-652$

Luck MR, Müker M and Praetorius C (1991) Autocrine control of phenotype by extracellular matrix proteins in luteinizing granulosa cells Journal of Reproduction and Fertility Supplement 43 101-102

Luck MR, Zhao $\mathrm{Y}$ and Silvester LM (1995) Identification and localization of collagen types I and IV in the ruminant follicle and corpus luteum Journal of Reproduction and Fertility Supplement 49 517-526

Miller EJ and Rhodes RK (1982) Preparation and characterization of the different types of collagen Methods in Enzymology 82 33-64

Morrison KE, Germino GG and Reeders ST (1991a) Use of the polymerase chain reaction to clone and sequence a cDNA encoding the bovine $\alpha 3$ chain of type IV collagen Journal of Biological Chemistry $26634-39$

Morrison KE, Mariyama M, Yang-Feng TL and Reeders ST (1991b) Sequence and localization of a partial cDNA encoding the human $\alpha 3$ chain of type IV collagen American Journal of Human Genetics 49 545-554

Myers JC, Brinker JM, Kefalides NA, Rosenbloom J, Wang SY and Gudas LJ (1986) Discrimination among multiple AATAAA sequences correlates with interspecies conservation of select $3^{\prime}$ untranslated nucleotides Nucleic Acids Research 14 4499-4517

Pikkarainen T, Eddy R, Fukushima Y, Byers M, Shows T, Pihlajaniemi T, Saraste M and Tryggvason K (1987) Human laminin B1. A multidomain protein with gene (LAMB1) locus in the 922 region of chromosome 7 Journal of Biological Chemistry $26210454-10462$ 
Pikkarainen T, Kallunki T and Tryggvason K (1988) Human laminin B2 chain comparison of the complete amino acid sequence with the BI chain reveals variability in sequence homology between different structural domains Journal of Biological Chemistry 263 6751-6758

Skinner MK and Dorrington JH (1984) Control of fibronectin synthesis by rat granulosa cells in culture Endocrinology 115 2029-2031

Skinner MK, McKeracher HL and Dorrington JH (1985) Fibronectin as a marker of granulosa cell differentiation Endocrinology 117 886-892

Timpl R, Rohde H, Robey PG, Rennard SI, Foidart JM and Martin GR (1979) Laminin - a glycoprotein from basement membranes Journal of Biological Chemistry 254 9933-9937
Towbin H, Staehlin T and Gordon J (1979) Electrophoretic transfer of proteins from polyacrylamide gels to nitrocellulose sheets: procedures and some applications Proceedings of the National Academy of Sciences USA 76 4350-4354

van der Rest M and Garrone R (1991) Collagen family of proteins FASEB journal 5 2814-2823

Wordinger RJ, Rudick VL and Rudick MJ (1983) Immunohistochemical localization of laminin within the mouse ovary Journal of Experimental Zoology 228 141-143

Zheng J, Redmer DA and Reynolds LP (1993) Vascular development and heparin-binding growth factors in the bovine corpus luteum at several stages of the estrous cycle Biology of Reproduction 49 1177-1189 